\title{
Implementasi Kurikulum Berbasis IT dalam Sekolah dimasa Pandemi Covid-19
}

\author{
Sugiati \\ SDN Petemon Surabaya \\ Jl. Tidar No. 121 Kecamatan Sawahan Kota Surabaya \\ sugiatisuyitno@gmail.com
}

\begin{abstract}
This study aims to implement the curriculum by utilizing information and communication technology during the pandemic which in the process is distance learning. Teachers without face-to-face with students are expected to continue to maximize the learning process and maintain the quality of graduates by utilizing technology. The curriculum which is used as the spirit of education in schools is expected to be a reference for future learning progress. Whether or not the process is progressing or not, the success or failure of the process all depends on the curriculum developed by the school. This implementation must involve all stakeholders by preparing the readiness of the infrastructure and human resources owned by the infrastructure readiness teachers, at least the government procures funds for infrastructure facilities such as computers, internet connections, while for the readiness of teacher human resources, schools hold training on the use of MO365 from the Surabaya City Education Office and Google account suite. learn ID from the Ministry of Education and Culture. The implementation includes, the preparation of 1 curriculum documents using the D-One application, the preparation of lesson plans without printing or paperless, for file storage also using Google Drive or One Drive, preparing questions using office forms, vicon learning using Zoom Meet, Teams Meet, and Google. meet, entry of grades using an online report card application, besides that the school also has a website, Instagram, YouTube for publication of school activities. The school minimizes if there are obstacles related to the implementation of the IT-based curriculum by completing multimedia facilities and providing training to teachers in IT skills. The results of the implementation of the IT-based curriculum show that the achievement of the curriculum targets is above $80 \%$ as evidenced by the learning outcomes of students, as well as responses from school activities that have been published through the school's website, Instagram and YouTube.
\end{abstract}

Keywords: Implementation, Curriculum, IT Based, Pandemic Period

\begin{abstract}
Abstrak
Penelitian ini bertujuan untuk mengimplementasikan kurikulum dengan memanfaatkan teknologi informasi dan komunikasi dimasa pandemi yang dalam prosesnya adalah pembelajaran jarak jauh. Guru tanpa tatap muka dengan peserta didik diharapkan tetap memaksimalkan proses pembelajaran serta tetap mempertahankan kualitas mutu lulusan dengan memanfaatkan teknologi. Kurikulum yang dijadikan sebagai rohnya pendidikan disekolah diharapkan dapat sebagai acuan tentang progres pembelajaran ke depan. Maju tidaknya, berhasil tidaknya proses tersebut semua bergantung pada kurikulum yang dikembangkan oleh sekolah. Implementasi ini harus melibatkan seluruh stakeholder dengan mempersiapkan kesiapan sarpras dan SDM yang dimiliki oleh pengajar kesiapan sarpras setidaknya pemerintah melakukan pengadaan dana untuk sarpras misalkan perangkat komputer, sambungan internet sedangkan untuk kesiapan SDM guru, sekolah mengadakan pelatihan pemanfaatan MO365 dari dispendik kota surabaya dan Google suite akun belajar id dari kemendikbud. Implementasi nya meliputi, penyusunan dokumen 1 kurikulum menggunakan aplikasi D-One, penyusunan RPP tanpa cetak atau secara paperless, untuk penyimpanan file juga menggunakan google drive atau one drive, penyusunan soal menggunakan form office, pembelajaran vicon menggunakan zoom meet, teams meet, da google meet, pengentrian nilai menggunakan aplikasi rapor online, selain itu sekolah juga memiliki website, instagram, youtube untuk media publikasi kegiatan sekolah. Sekolah meminimalisir jika terjadi kendala terkait pelaksanaan imlementasi kurikulum berbasis IT dengan melengkapi sarana multimedia dan memberi pelatihan pada guru-guru dalam kemampuan IT. Hasil implementasi kurikulum berbasis IT menunjukkan bahwa ketercapaian target kurikulum mencapai diatas $80 \%$ dibuktikan dengan hasil belajar peserta didik, serta respon dari kegiatan sekolah yang telah dipublikasikan melalui website, intagram dan youtube sekolah.
\end{abstract}

Kata kunci: Implementasi, Kurikulum, Berbasis IT, Masa Pandemi

Copyright (c) 2021 Sugiati

Corresponding author: Sugiati

Email Address: sugiatisuyitno@gmail.com (Jl. Tidar No.121 Kecamatan Sawahan Kota Surabaya)

Received 09 September 2021, Accepted 06 October 2021, Published 17 November 2021 


\section{PENDAHULUAN}

Kurikulum menurut UU No. 20 tahun 2003 pasal 1 ayat (19), konstitusi menyatakan bahwa kurikulum adalah seperangkat rencana dan pengaturan mengenai tujuan, isi dan bahan pelajaran serta cara yang digunakan sebagai pedoman penyelenggaraan kegiatan pembelajaran untuk mencapai tujuan pendidikan tertentu. Pada perkembangannya, kurikulum menjadikan TIK sebagai bagian dari kajian subject matter yang harus dipelajari oleh peserta didik dan TIK juga mempengaruhi model pengembangan kurikulum. Dengan demikian lahirnya model-model pembelajaran yang berbasis TIK seperti e-learning, virtual learning, open and distance learning tidak terpisah dari kurikulum.

Penjelasan mengapa dilaksanakan PJJ (pembelajaran jarak jauh) atau SFH school from home yaitu menurut Permendikbud No. 109/2013 (Pasal 2), PJJ adalah suatu sistem pendidikan yang memiliki karakteristik terbuka, belajar mandiri dan belajar tuntas dengan memanfaatkan TIK.

Pandemi Covid-19 telah ditetapkan Presiden Republik Indonesia sebagai kedaruratan kesehatan dan bencana nasional non-alam. Sesuai dengan Surat Keputusan Bersama (SKB) Menteri Pendidikan dan Kebudayaan (Mendikbud), Menteri Agama (Menag), Menteri Kesehatan (Menkes), dan Menteri Dalam Negeri (Mendagri), sebagai upaya untuk mencegah penyebaran Covid-19 serta mengutamakan kesehatan dan keselamatan warga pendidikan. Setidaknya ratusan ribu sekolah ditutup untuk mencegah penyebaran Covid-19, sekitar 68 juta siswa melakukan kegiatan belajar dari rumah, serta sekitar 4 juta guru melakukan kegiatan belajar mengajar di luar sekolah. Berdasarkan data terakhir, penambahan kasus harian di tanah air sebanyak 5.008 kasus dan menjadikan kasus secara akumulatif berjumlah 1.501.093 kasus. Dari jumlah itu, terdapat 123.694 kasus aktif, 40.581 kasus meninggal, dan sisanya telah sembuh.

Guna memastikan hak belajar setiap anak terpenuhi, Mendikbud telah meluncurkan beberapa inovasi untuk mendukung pelaksanaan belajar dari rumah sesuai arahan Presiden. Beberapa inovasi tersebut di antaranya adalah kebijakan penggunaan dana bantuan operasional sekolah (BOS), penayangan program belajar dari rumah yang disiarkan di SBO bagi guru dan siswa, peluncuran portal guru berbagi, penyediaan bantuan subsidi kuota internet untuk siswa dan guru.

Dalam rangka meringankan kesulitan pembelajaran di masa pandemi, Pemerintah menyiapkan dukungan kebijakan pelaksanaan kurikulum di masa khusus, yakni satuan pendidikan dapat 1) tetap menggunakan kurikulum nasional; 2) menggunakan kurikulum darurat yang disusun oleh Mendikbud; dan 3) melakukan penyederhanaan kurikulum secara mandiri.

Manfaat IT untuk pengembangan kurikulum dimasa pandemi yaitu IT dapat digunakan untuk pengelolaan data, sebagai alat komunikasi antar institusi pendidikan, pusat pengembangan materi ajar, media pengembangan kurikulum, dan sebagai komunitas perbandingan standar kompetensi. Maka dari itu, penggunaan teknologi informasi dan komunikasi sangat penting untuk proses pembelajaran jarak jauh, pembelajaran menjadi lebih mudah dan menyenangkan, mempermudah komunikasi, menarik perhatian siswa, dan sebagainya. 


\section{Masa Pandemi}

Dunia saat ini sedang menghadapi pandemi yang disebabkan oleh SARS-CoV-2 (virus Corona) dan infeksinya yang disebut COVID-19. Infeksi virus ini awalnya ditemukan di Wuhan, Cina pada Desember 2019 dan telah menyebar dengan cepat ke berbagai belahan dunia. Pandemi ini mempengaruhi berbagai perubahan di sektor sosial ekonomi seluruh wilayah yang terjangkit, dan bukan hanya Cina saja. Berdasarkan data yang dilansir dari Satgas COVID-19, tertanggal 21 April 2020, sudah terkonfirmasi bahwa COVID-19 telah menginfeksi 6760 orang di Indonesia dengan angka kematian sebesar 590 orang dan 747 orang dinyatakan telah berhasil sembuh.

Wabah Corona memberikan dampak terhadap seluruh bidang, selain melumpuhkan kegiatan ekonomi, di bidang pendidikan juga sangat berdampak yaitu proses pembelajaran yang awalnya secara tatap muka dirubah menjadi pembelajaran dalam jaringan / daring. Peserta didik tidak wajib ke sekolah hanya dirumah belajar secara online. Hal tersebut dilakukan untuk mencegah penyebaran wabah Corona.

Selain proses pembelajaran dilakukan secara daring, untuk mencegah penyebaran wabah Corona maka Pemerintah melakukan PSBB yaitu Pembatasan Sosial Berskala Besar. Dan sekarang dilanjut dengan PPKM (Pemberlakuan Pembatasan Kegiatan Masyarakat) Mikro. Masa tersebut disa disebut juga dengan masa pandemi.

Masa pandemi disebut sebagai suatu wabah penyakit global. Menurut World Health Organization (WHO), pandemi dinyatakan ketika penyakit baru menyebar di seluruh dunia melampaui batas. Istilah pandemi menurut KBBI dimaknai sebagai wabah yang berjangkit serempak di mana-mana meliputi daerah geografi yang luas.

\section{Implementasi}

Implementasi adalah suatu tindakan atau pelaksanaan rencana yang telah disusun dengan cermat dan rinci. Implementasi ini biasanya selesai setelah dianggap permanen.

Implementasi ini tidak hanya aktivitas, tetapi suatu kegiatan yang direncanakan dan dilaksanakan dengan serius dengan mengacu pada norma-norma tertentu mencapai tujuan kegiatan. Oleh karena itu, pelaksanaan tidak berdiri sendiri tetapi dipengaruhi oleh objek berikutnya.

Sehingga implementasi adalah suatu pelaksanaan kegiatan yang terencana untuk mencapai tujuan kegiatan.

\section{Kurikulum}

Definisi kurikulum menurut Undang-Undang No.20 Tahun 2003 yaitu seperangkat rencana dan pengaturan mengenai tujuan, isi, dan bahan pelajaran serta cara yang digunakan sebagai pedoman penyelenggaraan kegiatan pembelajaran untuk mencapai tujuan pendidikan tertentu.

Sedangkan menurut Prof. Dr. S. Nasution, M.A dalam bukunya yang bertajuk Kurikulum dan Pengajaran, beliau menyatakan bahwa kurikulum adalah serangkaian rencana yang disusun demi melancarkan proses belajar-mengajar. Rencana tersebut dilakukan di bawah bimbingan dan tanggung jawab lembaga pendidikan dan para pengajar di lembaga tersebut. 
Sejalan dengan Dr. H. Nana Sudjana dalam bukunya yang berjudul Pembinaan dan Pengembangan Kurikulum di Sekolah, beliau berpendapat bahwa kurikulum merupakan kumpulan niat dan harapan yang tertuang dalam bentuk program pendidikan yang mana dilaksanakan oleh guru di sekolah.

Jadi, dapat disimpulkan bahwa kurikulum juga merupakan alat atau saran yang dirumuskan demi tercapainya tujuan pendidikan melalui proses pengajaran. Setelah pemerintah memutuskan untuk SFH (School From Home) karena wabah covid-19, Kemendikbud menerbitkan Keputusan Menteri Pendidikan dan Kebudayaan Republik Indonesia Nomor 719/P/2020 tentang Pedoman Pelaksanaan Kurikulum pada Satuan Pendidikan dalam Kondisi Khusus. Satuan pendidikan dalam kondisi khusus dapat menggunakan kurikulum yang sesuai dengan kebutuhan pembelajaran peserta didik.

Pelaksanaan kurikulum pada kondisi khusus bertujuan untuk memberikan fleksibilitas bagi satuan pendidikan untuk menentukan kurikulum yang sesuai dengan kebutuhan pembelajaran peserta didik. Satuan pendidikan pada kondisi khusus dalam pelaksanaan pembelajaran dapat 1) tetap mengacu pada Kurikulum Nasional; 2) menggunakan kurikulum darurat; atau 3) melakukan penyederhanaan kurikulum secara mandiri.

Kurikulum darurat (dalam kondisi khusus) yang disiapkan oleh Kemendikbud merupakan penyederhanaan dari kurikulum nasional. Pada kurikulum tersebut dilakukan pengurangan kompetensi dasar untuk setiap mata pelajaran sehingga guru dan siswa dapat berfokus pada kompetensi esensial dan kompetensi prasyarat untuk kelanjutan pembelajaran di tingkat selanjutnya. intinya adalah siswa tidak dibebani tuntutan menuntaskan seluruh capaian kurikulum untuk kenaikan kelas maupun kelulusan, dan pelaksanaan kurikulum berlaku sampai akhir tahun pelajaran.

Pemerintah juga melakukan relaksasi peraturan untuk guru dalam mendukung kesuksesan pembelajaran di masa pandemi. "Guru tidak lagi diharuskan untuk memenuhi beban kerja 24 jam tatap muka dalam satu minggu sehingga guru dapat fokus memberikan pelajaran interaktif kepada siswa tanpa perlu mengejar pemenuhan jam. Sedangkan dalam satu jam pelajaran hanya 25 menit, dan semua itu sudah disematkan dalam aplikasi D-One berbasis IT yang didalamnya ada Penyederhanaan KD dan beban kerja guru.

\section{Teknologi dan Informasi}

Teknologi merupakan segala cara dan proses yang dilaksanakan dengan menggunakan perangkat sebagai upaya untuk mewujudkan sesuatu secara rasional agar menjadi lebih mudah dan efektif. Dalam hal ini perangkat yang digunakan ialah yang berbasis komputer. Tidak dipungkiri bahwa teknologi kini berkembang begitu pesat. Di saat itu pula, masyarakat dituntut tetap bertahan dan beradaptasi di tengah perkembangan zaman. Masyarakat Indonesia kini sedang memasuki era society 5.0 atau era masyarakat dimana masyarakat dunia kini banyak menggunakan teknologi digital baik mengguakan komputer atau gadget android. Era society 5.0 diperkenalkan kepada masyarakat agar tetap dapat mengendalikan teknologi yang mereka ciptakan, dimana masyarakat kini telah 
banyak menggunakan teknologi digital, artinya semua menggunakan paperless atau tanpa kertas, terutama di masa pandemi Covid 19.

Adopsi teknologi digital dan penerapan paperless society adalah salah satu cara untuk menekan penggunaan kertas di era digital. RPP dan perangkat pembelajaran yang sebelumnya ditulis tangan di atas kertas kini bisa diketik dan dikirim secara digital. Segala laporan yang sebelumnya harus dicetak dan diberikan secara langsung kepada pihak yang ditagih kini dapat dikirim melalui aplikasi. Seperti laporan absensi, SKP, kenaikan pangkat dan lain-lain dengan menggunakan siagus (aplikasi guru Surabaya).

Menurut Sutanta (2011) informasi merupakan sebuah hasil dari pengolahan data sehingga menjadi bentuk yang penting bagi si penerima informasi. Dengan adanya informasi, dapat dijadikan sebagai dasar untuk pengambilan keputusan oleh si penerima informasi, yang mana dapat dirasakan akibatnya baik secara langsung maupun tidak langsung.

Aplikasi Teknologi Informasi di dunia pendidikan antara lain sebagai perangkat lunak pengajaran, memberikan fasilitas untuk mahasiswa atau siswa untuk belajar mengambil keuntungan dari TI, belajar jarak jauh, informasi dan pengetahuan tentang pendidikan. Menurut Davies (dalam Suyanto: 326), penggunaan perangkat lunak TI dalam proses pembelajaran akan meningkatkan efisiensi, meningkatkan motivasi, memberi fasilitas belajar aktif memfasilitasi belajar eksperimental, konsisten dengan belajar yang berpusat pada siswa dan memandu untuk belajar lebih baik.

Teknologi Informasi sebagai media pendidikan dilakukan dengan menggunakan media-media komunikasi seperti telepon, komputer, internet, email, dan sebagai berikut. Interaksi antara guru dan muridnya tidak hanya dilakukan melalui hubungan tatap muka tetapi juga dilakukan dengan menggunakan media-media tersebut. Guru dapat memberikan layanan tanpa harus berhadapan langsung dengan muridnya. Demikian pula siswa dapat memperoleh informasi dalam lingkup yang luas dari berbagai sumber melalui aplikasi Microsoft teams dan website sekolah.

Pendapat tersebut juga diperkuat oleh Heinich dalam Bambang Warsita (2008:137-144), TI merupakan segala bentuk pemanfaatan komputer dan internet untuk pembelajaran. Bentuk pemanfaatan teknologi informasi yakni: 1) Tutorial, merupakan progam yang dalam penyampaian materinya dilakukan secara tutorial, yakni suatu konsep yang disajikan dengan teks, gambar baik diam atau bergerak dan grafik; 2) Praktik dan latihan (drill and practice), yaitu untuk melatih peserta didik memiliki kemahiran dalam suatu keterampilan atau memperkuat penguasaa suatu konsep. Progam ini biasanya menyediakan serangkaian soal atau pertanyaan; 3) Simulasi (simulation), yaitu format ini bertujuan untuk mensimulasikan tentang suatu kejadian yang sudah terjadi maupun yang belum dan biasanya berhubungan dengan suatu resiko, seperti pesawat akan jatuh atau menabrak, terjadinya malapetaka dan sebagainya; 4) Percobaan atau eksperimen, format ini mirip dengan format stimulasi, namun lebih ditujukan pada kegiatan-kegiatan eksperimen, seperti kegiatan praktikum di laboratorium IPA, Biologi atau Kimia; 5) Permainan (game), yaitu mengacu pada proses pembelajaran dan dengan progam multimedia berformat ini diharapkan terjadi aktivitas belajar sambil bermain. 
Dari berbagai pendapat di atas dapat disimpulkan bahwa manfaat IT adalah sebagai berikut : pertama, TI sebagai sumber yakni IT dapat dimanfaatkan untuk sumber informasi dan untuk mencari informasi yang akan dibutuhkan. Kedua, IT sebagai media, sebagai alat bantu yang memfasilitasi penyampaian suatu informasi agar dapat diterima dan dimengerti dengan mudah. Ketiga, IT sebagai pengembang keterampilan pembelajaran, pengembangan keterampilan-keterampilan berbasis teknologi informasi dengan aplikasi-aplikasi dalam kurikulum seperti D-One, Siagus, Microsoft Office 365, Google suite, website dan lain-lain.

\section{Diskusi}

\section{Kurikulum Berbasis IT}

Pandemi covid 19 telah membawa dampak terhadap penyelenggaraan pendidikan baik di sekolah formal maupun non formal mulai jenjang TK sampai Perguruan Tinggi. Dengan demikian sangat diperlukan adanya adaptasi dan perubahan pada sistem pembelajaran. Terkait dengan permasalahan tersebut Kemendikbud telah memberlakukan kurikulum darurat yang berlaku untuk masa pembelajaran tahun 2020/2021. Kurikulum darurat pada hakikatnya merupakan penyederhanaan kurikulum, yakni dengan mengurangi jumlah kompetensi dasar pada tiap tiap mata pelajaran.

Selain penyederhanaan kurikulum sebagaimana terurai di atas, adaptasi kurikulum di masa pandemi bisa berupa pemanfaatan teknologi informasi dan komunikasi. Teknologi informasi dan komunikasi tersebut dimanfaatkan sebagai inovasi pembelajaran dalam menghadapi masa pandemi yang mewajibkan kita untuk menjaga jarak antara satu dengan yang lain. Social distancing merupakan satu hal yang menyebabkan kita sebagai guru untuk menyampaikan materi pembelajaran secara daring. Pembelajaran secara daring (online) tentu membutuhkan media pembelajaran yang berbasis teknologi. Dengan demikian adaptasi dan pengembangan kurikulum di masa pandemi harus berbasis pada teknologi, khususnya teknologi informasi dan komunikasi. Dukungan teknologi tersebut sangat diperlukan agar target pencapaian kurikulum bisa tercapai meskipun di masa pandemi.

Pengembangan kurikulum berbasis teknologi ini sesuai dengan salah satu landasan kurikulum yaitu landasan teknologis. Landasan teknologis artinya kurikulum harus mampu menyesuaikan dengan teknologi yang ada, mengadopsi dan menjadikan teknologi tersebut menjadi isi kurikulum yang akan dipelajari oleh peserta didik. Berkenaan dengan proses, teknologi mempunyai banyak peran dan fungsi. Yang pertama, teknologi mempermudah proses implementasi kurikulum baik untuk menunjang manajemen kurikulu, maupun administrasi kurikulum. Kegiatan yang berbasis adminitrasi di sekolah sangat dipermudah dengan teknologi komputer, proyektor, hand phone dan lain lain. Yang kedua, teknologi berfungsi sebagai media pembelajaran. Teknologi yang dimanfaatkan sebagai media pembelajaran dapat meningkatkan hasil dan pengalaman belajar peserta didik. Penggunaan proyektor, komputer. Laptop, dan lain lain sangat membantu guru dalam menyampaikan materi pembelajaran kepada siswa, khususnya materi pembelajaran yang sulit dan rumit sehingga perlu didukung dengan media pembelajaran.

Guru dan siswa dituntut untuk menguasai ilmu pengetahuan dan teknologi informasi 
komunikasi secara terus menerus. Guru perlu terus mengikuti perkembangan ilmu pengetahuan dan teknologi informasi komunikasi agar dapat menyampaikan materi pembelajaran yang mutakhir dan berguna bagi kehidupan siswa di masa kini dan masa yang akan datang. Dengan demikian, pengembangan kurikulum yang berbasis teknologi informasi dan komunikasi sebagai produk dari perkembangan ilmu pengetahuan dan teknologi dalam sistem pendidikan nasional sudah tidak dapat dipisahkan. Hal ini sejalan dengan upaya inovasi kurikulum yang seiring dengan kemajuan ilmu pengetahuan dan teknologi dalam semua sisi kehidupan.

Penguasaan ilmu pengetahuan dan teknologi diupayakan untuk mencapai tujuan pendidikan. Tujuan tersebut akan terwujud melalui kurikulum yang dirancang dengan memperhatikan aspek-aspek kebutuhan peserta didik, perkembangan ilmu dan teknologi, tuntutan masyarakat serta berdasarkan analisis situasi yang ada. Perkembangan teknologi yang terjadi dewasa ini turut mempengaruhi kurikulum. Pada perkembangannya, kurikulum menjadikan TIK sebagai bagian yang harus dipelajari oleh peserta didik. Dengan demikian lahirnya model-model pembelajaran yang berbasis TIK seperti elearning, virtual learning, Computer Based Training, Open and Distance Learning tidak terpisah dari kurikulum

Hal hal yang perlu di persiapkan untuk pengimplementasian kurikulum yang berbasis IT:

1. Sarana dan prasarana sekolah

Sarana dan pra sarana tersebut antara lain komputer, perangkat internet, dan gawai. Berkenaan dengan komputer, ditemukan bahwa sebagian besar lembaga memiliki komputer tetapi jumlah komputernya. sangat sedikit. Tiap sekolah kondisinya jelas berbeda beda. Ada sebagian sekolah yang sudah mempunyai komputer dengan jumlah yang memadai, namun masih banyak sekolah yang belum mempunyai perangkat komputer dengan jumlah yang memadai. Begitu juga dengan gawai. Meskipun hampir tiap orang sudah memiliki hand phone akan tetapi untuk menjangkau tuntutan pembelajaran yang berbasis TIK tentu tidak semua handphone bisa dimanfaatkan dan mendukung untuk tujuan tersebut. Yang terakhir, akses internet harus mendukung. Ini kelihatannya sepele tetapi kenyataannya tidak semua sekolah bisa mewujudkannya.

\section{Kompetensi Guru}

Sumber daya manusia yang ada di sekolah antara lain Kepala Sekolah, guru, siswa, staf tata usaha sekolah, tenaga keamanan, dan lain lain. Guru menjadi komponen yang utama di sekolah. Guru harus memiliki kesiapan untuk menerapkan kurikulum berbasis TIK di sekolah dengan segala kekurangan permasalahan yang ada, sesuai dengan kondisi sekolahnya masing masing. Dalam proses pembelajaran guru bertugas untuk mendidik, mengajar, membimbing, mengarahkan, menilai, dan diakhiri dengan mengevaluasi pada peserta didiknya. Proses pembelajaran dapat berjalan dengan baik dengan memperhatikan dua hal yaitu metode pembelajaran dan media pembelajaran. Penggunaan media pembelajaran diharapkan dapat membawa peran seorang guru untuk bisa lebih inovatif dan produktif dalam menyajikan materi yang disampaikan kepada siswa di kelas. Pemanfaatan TIK dalam media pembelajaran 
diharapkan memiliki kontribusi dan inovasi yang besar pada dunia pendidikan. Adanya TIK diharapkan dapat memberikan kemudahan bagi guru dalam meningkatkan kemampuan mengajarnya di dalam kelas. Selain bisan mengoperasikan komputer guru juga harus bisa menggunakan berbagai macam aplikasi yang berkaitan dengan tugas pokok guru maupun berbagai informasi lainnya, misalnya aplikasi LMS dari dinas pendidikan dan kemendikbud.

3. Dukungan Orang Tua/Walimurid

Orang tua/walimurid sebagai salah satu komponen dalam sistem pendidikan yang mempunyai peran, kontribusi, dan pengaruh terhadap keberhasilan pendidikan. Dengan penerapan kurikulum berbasis TIK ini peran orang tua baik dari segi dukungan moril maupun fasilitas untuk anaknya justru semakin besar. Kurikulum berbasis TIK menuntut tiap siswa memiliki perangkat gawai untuk mendukung berbagai macam aktifitas dan variasi pembelajaran yang berbasis TIK. Ini tidak mudah, karena setidaknya siswa mempunyai perangkat handphone yang bisa digunakan semua aktifitas pembelajaran daring atau pembelajaran secara on line, dan lain lain.

Dari segi kemampuan tentu berbeda beda antara orang tua/Wali murid yang satu dengan yang lainnya. Di sisi lain orang tua juga mempunyai peran dan tanggung jawab yang besar untuk mengawasi anaknya dalam menggunakan handphone. Kewajiban ini tidak bisa diremehkan begitu saja, karena dampak negatif penggunaan hand phone pada anak anak sangat besar. Waktu anak anak di luar sekolah cukup banyak, sehingga pengawasan orang tua amat diperlukan.

4. Peran Pemerintah

Pemerintah dalam hal ini Kemendikbud telah banyak memberikan perhatian, khususnya terkait dengan penyelenggaran pembelajaran di masa pandemi covid 19. Sejak Maret 2020, Kemendikbud telah melakukan penyesuaian kebijakan pendidikan, serta menyediakan inisiatif dan solusi di masa pandemi Covid-19. Pada bulan Maret, terdapat pembatalan ujian nasional, ujian sekolah tidak perlu mengukur ketuntasan kurikulum, sekolah yang belum melaksanakan ujian dapat menggunakan nilai lima semester terakhir untuk menentukan kelulusan siswa, mekanisme PPDB tidak mengumpulkan siswa dan orang tua, PPDB jalur prestasi berdasarkan akumulasi nilai rapor dan prestasi lain.

Pada bulan Maret tahun 2020, Kemendikbud melakukan penyediaan kuota gratis, realokasi anggaran Pendidikan Tinggi sebesar Rp 405 M untuk Rumah Sakit Pendidikan Perguruan Tinggi Negeri dan Perguruan Tinggi Swasta, realokasi anggaran Kebudayaan Rp 70 M untuk kegiatan Belajar dari Rumah melalui TVRI, peluncuran portal Guru Berbagi, relaksasi penggunaan BOS dan BOP. Relaksasi penggunaan anggaran BOS dan BOP antara lain untuk pembayaran honor guru, dan untuk kegiatan pembelajaran daring. Pada bulan Juli s.d. Agustus 2020, sekolah di zona hijau dan kuning diperbolehkan melakukan pembukaan kembali, zona lain masih dilarang, peluncuran kurikulum dalam kondisi khusus, dan Pemberian modul pembelajaran bagi PAUD dan SD.

Salah satu wujud perhatian Pemerintah adalah bantuan paket internet untuk kegiatan 
pembelajaran daring. Kemendikbud juga akan memberikan bantuan subsidi kuota internet untuk siswa, guru, mahasiswa dan dosen selama empat bulan. Besaran bantuan,kuota internet antara lain siswa $35 \mathrm{~GB} /$ bulan, guru $42 \mathrm{~GB} /$ bulan, serta mahasiswa dan dosen $50 \mathrm{~GB} / \mathrm{bulan}$

5. Kerjasa tim IT di sekolah

Kepala sekolah membentuk tim IT di sekolah tujuannya adalah sebagai tenaga yang mempersiapkan segala sesuatu terkait dengan penggunaan sarana sekolah yang berbasis IT, dan tentunya tim IT terdiri dari guru yang mumpuni dalam bidang computer. Selain itu tugas tim IT adalah mengantisipasi jika ada kendala baik dari sarana it maupun dari guru tentang masalah IT.

\section{Implementasi Kurikulum Berbasis IT di Sekolah}

Penerapan kurikulum berbasis IT di Sekolah dilaksanakan sebagai respon dan adaptasi kebijakan sekolah terhadap situasi pandemi covid 19 dan berbagai kebijakan Pemerintah yang mengharuskan kita melaksanakan pembelajaran secara daring melalui berbagai macam media dan aplikasi yang ada. Namun secara umum dan lebih luas kita menyusun dan melaksanakan kurikulum berbasis IT mulai penyusunan dokumen I sampai kegiatan evaluasi pembelajaran. Berikut ini uraian pelaksanaan kurikulum berbasis IT di Sekolah.

1. Penyusunan dokumen 1 kurikulum

Dukumen 1 kurikulum merupakan perangkat kurikulum, mulai paparan visi misi sekolah hingga Rencana Pelaksanaan Pembelajaran sudah disusun menyesuaikan dengan kondisi pandemi covid 19. Target kurikulum dan Rencana Pelaksanaan Pembelajaran (RPP) sudah disesuaikan dengan kondisi sekarang ini. Ada hal yang pokok berkaitan dengan kegiatan pembelajaran dimasa pandemi, yakni kegiatan pembelajaran dilaksanakan dengan daring dan juga luring. Secara umum kegiatan pembelajaran dilaksanakan dengan daring menggunakan berbagai media dan aplikasi, seperti WhatsApp, Zoom, Teams, Sway, dan lain lain. Ada beberapa cara yang bisa dilakukan oleh guru dalam menyampaikan materi pembelajaran kepada siswa. Ada yang menyampaikan materi pembelajaran dalam melalui Sway atau mengirim soal melalui Microsof Office 365 yang kemudian dikirim dalam bentuk link. Ada beberapa siswa yang bisa mengikuti pembelajaran melalui Zoom atau Teams.Namun ada beberapa siswa yang belum mempunyai hand phone yang mendukung untuk pembelajaran daring tetap kita berikan pembelajaran dengan luring, yakni dengan diberikan tugas kemudian setiap hari Sabtu tugas tersebut dikumpulkan. Kegiatan penyusunan dokumen 1 SDN Wonokusumo VI sudah menggunakan aplikasi D-One.

2. Penyusunan dan Pengarsipan RPP

Penyusunan Rencana Pelaksanaan Pembelajaran (RPP) tdk lagi di cetak akan tetapi kami simpan di file pdf atau word dg telah di sahkan menggunakan tanda tangan specimen atau scan. Kegiatan tersebut dilaksanakan di awal semester. Jadi di awal semester bapak dan Ibu guru sudah mengumpulkan RPP dengan dikoordinir oleh Koordinator kelasnya masing masing. Tanda tangan guru dan Kepala sekolah menggunakan tanda tangan specimen atau scan. Selain memanfaatkan teknologi, ini dimaksudkan agar kita mengurangi penggunaan kertas. Lebih dari 
itu di masa pandemi inovasi tersebut bisa mengurangi resiko penularan covid 19.

\section{Pemanfaatan Microsof Office 365 dan Google Suite}

Dinas Pendidikan Kota Surabaya diawal masa pandemic memberikan akun Microsoft office 365 untuk guru dan siswa sebagai akun untuk pembelajaran secara jarak jauh. Akun dengan domain dispendik.surabaya.go.id tersebut dibeli oleh dinas pendidikan kota Surabaya dari Microsoft dengan dana yang tidak sedikit. Oleh karena itu dispendik nkota Surabaya mewajibkan seluruh guru dan siswa untuk memanfaatkan akun MO365 tersebut secara maksimal, walaupun akun tersebut sebenarnya masih ada kendala. Microsoft Office 365 terdiri dari beberapa platform untuk menunjang proses pembelajaran jarak jauh, diantaranya: 1) Microsoft Teams yaitu digunakan untuk pembelajaran vicon, memberikan tugas, pengumuman, serta menyampaikan materi pelajaran; 2) form office yaitu digunakan untuk membuat soal maupun surfey kepada siswa, adapun soal yang dibuat bisa berbentuk pilihan ganda, pilihan ganda kompleks, uraian, dan menjodohan; 3) Microsoft sway digunakan untuk media presentasi atau promosi baik oleh guru maupun siswa; 4) onedrive digunakan untuk media penyimpanan file secara online dengan kapasitas yang lumayan besar sekitar 15 gb. Lain halnya dengan Kemendikbud yang sebelumnya mengeluarkan akun belajar id dari Google suite. Akun ini gratis yang didapatkan dari data pada dapodik, Adapun siswa yang mendapatkan akun ini hanya terbatas yaitu hanya kelas tinggi yaitu kelas 4 dan 5 untuk SD, kelas 3 untuk SMP dan SMA, akun belajar id juga memiliki banyak keunggulan diantaranya banyak di dalamnya terdapat platform untuk menunjang pembelajaran diantaranya: 1) google classroom digunakan sebagai sarana memberikan tugas secara kolektif, 2) google form digunakan untuk pembuatan soal yang berupa pilihan ganda, pilihan ganda kompleks, isian singkat, uraian, menjodohkan, survey; 3) Google slide digunakan sebagai media presentasi; 4) google meet digunkan untuk pembelajaran secara vicon; 5) google drive yaitu media penyimpanan file secara online dengan kapasitas storage yang tak terbatas.

4. Rapat dan pembelajaran vicon menggunakan Teams, zoom meet dan google meet Dengan alasan pembatasan sosial dan menjaga jarak atau sosial distance, maka untuk rapat atau proses pembelajaran yang sebelumnya tatap muka maka diganti dengan vicon atau video teleconverence dengan menggunakan aplikasi zoom, meet teams, dan google meet. Dengan teta bisa membagikan materi presentasi dengan vitur share screen, serta video dapat direkam sehingga dapat diputar ulang.

5. Untuk analisis nilai soal menggunakan hasil respon yang berupa excel dan spreadsheet.

Dengan adanya membuat soal berupa form, maka respon hasil pengerjaan siswa berupa spreadsheet atau excel yang selanjutnya dapat dianalisis nilainya dengan memanfaatkan rumus yang ada pada excel.

6. Pengentrian nilai rapor menggunakan rapor online dari dispendik

Setelah nilai didapatkan dari analisis, selanjutnya nilai dipilah sesuai KKM, jika nilai masih dibawah KKM maka diadakan remidi, jika nilai diatas KKM maka diadakan pengayaan, Adapun 
nilai KKM sekolah ditentukan 80 yang sudah dientrikan dalam aplikasi D-One. Selajutnya niai tersebut dientrikan kedalam rapor online sesuai KD setiap mata pelajaran, tidak hanya itu, di rapor online juga mengisi daftar hadir siswa, nilai ekstrakurikuler siswa, serta Kesehatan siswa, selanjutnya nilai siswa akan dicetak berupa rapor siswa dan di simpan dalam bentuk pdf yang sudah ditandatangani secara spesimen (tanda tangan online).

7. Jurnal kegiatan, jurnal kelas, serta absensi pegawai menggunakan Siagus (aplikasi guru Surabaya)

Aplikasi siagus dari dispendik kota Surabaya memberikan banyak kemudahan misalnya laporan jurnal kelas, jurnal kegiatan, serta absensi pegawai yang secara otomatis akan tersimpan dan terkirim ke admin dispendik, sehingga tidak perlu laporan yang berupa kertas atau buku.

8. Pengadministrasian data sekolah, data guru, serta data siswa menggunakan aplikasi profil sekolah Segala bentuk administrasi untuk data sekolah, data guru, serta data siswa menggunakan aplikasi profil sekolah, dan profil sekolah digunakan sebagai acuan untuk laporan BOSDA, SKPBM online dan rapor online dispendik.

\section{Manfaat Implementasi Kurikulum berbasis IT di Sekolah}

1. Pembelajaran jarak jauh dapat terlaksana dengan baik dan lancar

2. Segala bentuk laporan sekarang menjadi lebih praktis karena secara paperless

3. Menghemat waktu dan biaya

4. Penyimpanan dokumen secara aman

\section{Kendala Pemanfaatan TIK dalam Kurikulum}

1. Sarana koneksi internet yang kadang kurang mendukung

2. Kemampuan guru yang kurang mumpuni

3. Walimurid yang kurang melek IT

4. Perangkat gadget siswa atau walimurid yang kadang kurang support

\section{Cara Mengatasi Kendala Pemanfaatan TIK dalam Kurikulum}

1. Mengusulkan bantuan kuota internet kepada smartfren dan kemendikbud

2. Memberikan pelatihan kepada guru tentang pemanfaatan media pembelajaran yang memanfaatkan IT, seperti pelatihan MO365 dan pelatihan google suite.

3. Memberikan pendampingan kepada siswa atau walimurid tentang pemanfaatan media belajar seperti MO365 dan google suite

4. Memberikan pelayanan kepada siswa dengan penugasan secara luring (tugas berupa kertas atau buku)

\section{KESIMPULAN}

Berdasarkan pemaparan di atas maka dapat disimpulkan bahwa: (1) implementasi kurikulum dengan memanfaatkan teknologi informasi dan komunikasi sangat efektif untuk menunjang proses pembelajaran dimasa saat ini yaitu pandemi covid. (2) Pelaksanaan kurikulum berbasis IT dimasa 
pandemi tidak akan berhasil tanpa partisipasi seluruh stake holder yaitu pemerintah, kepala sekolah, guru, siswa walmur, komite serta dukungan dana dan sarpras yang memadai.

Berdasarkan kesimpulan tersebut, hal yang penting dan perlu diperhatikan untuk menindak lanjuti hasil kegiatan ini adalah: (a) Sebelum implementasi kurikulum berbasis IT maka sarana dan prasarana serta SDM guru dan siswa harus di persiapkan terlebih dahulu dengan tepat, lengkap dan terencana. (b) Secanggih apapun teknologi, tidak akan dapat menggantikan peran guru sebagai pendidik. Maka dari itu Kemampuan guru harus mumpuni dalam mengaplikasikan kurikulum yang berbasis IT.

\section{UCAPAN TERIMA KASIH}

Terimakasih saya ucapkan kepada pengawas SD dan Guru-guru di SDN Petemon Surabaya yang telah membantu dan memberikan sumbangsih kepada peneliti dalam melaksanakan penelitian. Selain itu juga kepada seluruh stakeholder yang telah ikut berpartisipasi dalam melaksanakan penelitian ini.

\section{REFERENSI}

Aribowo, E. K. (2017c). Microsoft OneDrive: Media Penyimpanan Virtual Lintas Platform.

Firman, Sari Rahayu Rahman. (2020). Pembelajaran Online di Tengah Pandemi Covid-19. Sulawesi Barat: Universitas Sulawesi Barat. Vol. 2.

Kepmendikbud Nomor 719/P/2O2O Tentang Pedoman Pelaksanaan Kurikulum Pada Satuan Pendidikan Dalam Kondisi Khusus (Masa Pandemi).

Ridi Terdanu, Randi Eka, Ibnu Fauzi (2018) Petunjuk Praktis Microsoft Office 365 Bagi Institusi Pendidikan, Microsoft Innovation Centre Yogyakarta.

UU Nomor 20 Tahun 2003, Tentang Sistem Pendidikan Nasional.

Zaenal, A. (2011). Buku Pintar Google. Penerbit Media Kita. Jakarta Internet.

https://covid19.go.id/p/berita/kemendikbud-terbitkan-kurikulum-darurat-pada-satuan-pendidikandalam-kondisi-khusus 